\title{
LEO XIII: TWO CONCEPTS OF GOVERNMENT
}

\section{JOHN COURTNEY MURRAY, S.J. \\ Woodstock College}

$W^{\text {ITHIN }}$ the perspectives of Leo XIII's total teaching, the question of governmental cura religionis occupies a position of relatively minor importance. However, the question seems to cause trouble; hence an inquiry into it is indicated. The first step in the inquiry must be a study of the two concepts of government which are found in Leo XIII. The present article begins this study; it will be completed later. The full proposition will be threefold. First, Leo XIII assigns to government a strictly political role with regard to the socioeconomic order. However, secondly, in what concerns the order of religion and culture, he makes out the functions of government to be more than political; in this area a theory of government as also paternal in its functions, and therefore less limited, makes its appearance. Thirdly, if a reason for this difference is sought, it will be importantly found in the historical conditions which this particular Pope confronted.

\section{THE POLITICAL CONCEPT}

As the Social Question pressed more and more urgently upon the Christian conscience in the latter half of the nineteenth century, two general schools of thought developed in Catholic circles with regard to the role of government in its solution. In Germany, where discussion was most active, the so-called Minimists came to be led by Bishop Freppel. The other school, the so-called Interventionists, came under the more vigorous leadership of Bishop Ketteler. When Leo XIII finally issued Rerum novarum in 1891, he firmly took his stand with Ketteler. This was a bold move, not pleasing to many Catholics. But when the initial resistance had been dissipated, the move was seen to be providential. By it, as someone has remarked, Leo XIII took the revolutionary flavor out of a strong program of government intervention in the socio-economic order; this was a necessary step toward the solution of the Social Question. In our day the four classic texts are almost too well known to need quotation. 
First, Rerum novarum assigns to government a "general providence" over society. The broad principle is stated in this pregnant, if not altogether clear, sentence: "Those who are in power ought chiefly to give their assistance in general and all along the line, by the whole pattern of laws and institutions; in other words, they ought to bring it about that the prosperity both of the community and of private individuals may grow spontaneously out of the very structure and administration of the state." This broad principle is the general premise of possible intervention by government in the socio-economic order.

The second classic text states the conditions and limits of this governmental intervention: "If therefore any injury has been done, or threatens to be done to the interests of the community (rebus communibus) - the kind of injury which cannot otherwise be repaired or prevented-it is necessary for public authority to intervene.", 2 There follows an enumeration of the properly social kind of disorders which call for governmental action. The text then goes on: "In all these cases the force and authority of law obviously ought to be employed, within certain limits. And these limits are determined by the same principle which demands the aid of law-the principle, namely, that the law ought not to undertake more, nor ought it to go farther, than the remedy of evils or the removal of danger requires." ${ }_{3}$ This text makes clear that governmental intervention is hypothetical, per accidens, ad hoc.

A third classic text states the essential action required of government; it is action, not properly intervention. It is an action in favor of those free associations within the commonwealth upon which, according to the principles of right social order, there falls in the first instance the responsibility for promoting the particular social goods which integrate the common good: "Let the state protect these lawfully associated bodies of citizens; but let it not intrude into their internal affairs and order of life; for vital activity is set in motion by an interior principle, and it is very easily shattered by outside interference." ${ }_{4}$ This principle struck at the social theory and polity, individualist in philosophical origin and totalitarian in political tendency, which denied and de-

${ }^{1}$ Two Basic Social Encyclicals (Washington: Catholic University Press, 1943), Rerum novarum, n. 48 , p. 40; here and elsewhere I have emended the translation.

Ibid., n. 52, p. 47.

${ }^{3}$ Ibid., n. 53, p. 48.

Ibid., n. 75, p. 72. 
stroyed all intermediary institutions between the individual and the state.

The final classic text concerns the special duty of government to come to the aid of the "unhappy multitude, which has no security through resources of its own" (miserum vulgus, mullis opibus suis tutum $).{ }^{5}$ Leo XIII has specially in view the growing urban proletariat, the new social phenomenon brought forth by the Industrial Revolution. Not absent from his view, however, was the age-old peasant, who had long been a characteristic of the European scene. This text, therefore, takes account of actually prevalent conditions of social disorder.

All these principles received greater clarification and development as later thinkers reflected on the experience of developing industrial society. The fruit of their reflection was codified in Quadragesimo anno, which goes beyond the argument of Rerum novarum, especially in what concerns the principle of subsidiary function, the freedom of the various "orders" in society, and the generic duty of the political authority to aid in elaborating the structure of society, principally by aiding the growth of free socio-economic associations. ${ }^{6}$ These further developments need not be brought into view here; they are substantially in the line set by Leo XIII when he defined the relation of government to the social and economic order.

A less well known text may be quoted in conclusion; it is found in an allocution to a group of French workers, delivered in 1887. After recalling the past services of the Church to the poor and to the workers, "not only by largesse of charity, but by creating and encouraging those great corporative institutions which contributed so powerfully to the progress of the arts and crafts" as well as to the security of the worker, the Pope states this principle with regard to the socio-economic function of government:

Without a doubt, the intervention and action of these (public) powers are not indispensably necessary, when conditions in labor and industry reveal nothing

'Ibid., n. 54 , p. 48 ; cf. n. 49 , p. 42.

"No proper English equivalent has yet been found for the Latin, "ordines" and "collegia ordinum," of Pius XI. Tentatively, the terms "industry councils" and "industry council plan" have been adopted; cf. John F. Cronin, Catholic Social Principles (Milwaukee: Bruce, 1950), pp. 221-22. 
which offends against morality, justice, human dignity, the domestic life of the worker. But when any of these values is menaced or compromised, the public powers, intervening in proper fashion and in just measure, are to do a work of social salvation; for it falls to their charge to protect and safeguard the true interests of the citizens under their obedience. ${ }^{7}$

These texts assign to government a properly political task with regard to the socio-economic order. It is a political task, first, because it is prompted by the exigencies of properly social goods - the particular social goods of various groups as well as the general welfare as such. Political power does not act in the personal interests of the private individual as such. ${ }^{8}$ The task is political, secondly, because it is strictly limited; all political tasks are limited. The general principle of limitation is again the common good, as a whole or in its constituent parts. Concretely, the leading principle of limitation is the rightful and necessary freedom of society in all its associational forms to direct and govern itself, under the "general providence" of government. The freedom of society is an essential element of the common good; for in society, and not in government, reside the vital energies which make for public prosperity.

Consequently, the first criterion of governmental intervention is necessity - the necessity created by the fact that important human values are being damaged or menaced. Moreover, the damage must be substantive; the menace must be grave. Both must assume the proportions of a social evil. Furthermore, resort to government must be in the nature of a last resort; the damage must be irremediable, the danger irremovable, by any other agency. Again, as it is prompted by necessity, so governmental intervention must not be pushed beyond the limits of necessity: "... the law ought not to undertake more, nor ought it to go farther, than the remedy of evils or the removal of danger requires." Governmental action looks primarily to the restoration of an order of freedom; when this order is established, the free forces within the order again resume their rightful role.

Finally, governmental action is limited by its mode, which is the

${ }^{7}$ Allocution, Grande est la joie (Oct. 18, 1887), Desclée, III, 14.

8 "Since law of its nature envisages the common good, it would do wrong to concern itself with singular and rare cases; there is no need to fear that such cases would trouble that peace and tranquillity which is the proper end of political authority" (Bonne Presse, III, 180). 
political mode of law. Law is a necessary instrument of social order; its value, in fact, is measured by its necessity. However, its value is limited, even if it be regarded as a directive force, and still more limited if it be regarded as a coercive force. The more important forces that make for social order rise from the depths of the free human spiritthe forces of civic virtue, which gives birth to a love of the common good and to a spirit of voluntary cooperation towards its achievement; the forces of moral virtue, which instil a spirit of social justice and charity into all human associations; and above all the forces of religious faith, which are ultimately the ordering forces of all human life, social as well as individual.

This is the place to note the purely relative value that Leo XIII puts on human civil law and its directive and coercive force as a means towards social order. It is at times a necessary means, but always of itself an insufficient one. Texts in this sense abound; the following are typical. In the Encyclical, Diuturnum, after speaking of the dangers of communism, socialism, and nihilism, the Pope continues:

The more serious thing is that in the midst of these great dangers civil rulers do not have at their disposal sufficiently adequate means whereby public order may be restored and peace established among men. They arm themselves with the authority of laws; they think to coerce by the severity of punishments those who are disturbing society. This is right enough. But what needs serious consideration is the fact that the force of punishment can never be so great as of itself to preserve public order. Fear, as St. Thomas says, is a 'weak foundation'... One must make up one's mind that not even the severity of laws can be fruitful, unless men are moved by a sense of duty, and animated by a salutary fear of God.?

In the Encyclical, Exeunte iam anno, the ultimate premise of the inadequacy of human law as a redemptive force is laid down: man's redemption is ultimately found only in Christ:

Wherefore those who are endeavoring to extinguish the rising flames of passion among the populace by turning the force of law against them are indeed acting in the cause of justice. But let them understand that they will spend their labor with little or no result as long as they are obstinately determined to reject the virtue of the Gospel and to refuse the proffered assistance of the Church. The remedy for social evils lies in a change of heart, in a private and public return to Jesus Christ and to the Christian way of life. ${ }^{10}$

'Encyclical, Diulurnum (June 29, 1881), Desclée, I, 231.

${ }^{10}$ Encyclical, Exeunte iam anno (Dec. 4, 1888), Desclée, III, 194. 
One last text may be quoted from the Allocution, Il y a deux ans:

It behooves those who hold civil power to be penetrated with this truth, that, in order to dispel the danger that threatens society, neither human laws, nor repressions by magistrates, nor the arms of soldiers will be sufficient. What is above all else important, indeed indispensable, is that the Church should be afforded freedom to recall to men's mind the commands of God and to extend her saving influence throughout all classes of society. ${ }^{11}$

In the context of this question - the value of law in society-there recurs Leo XIII's endless, insistent theme, the necessity of religion in society, and to this end, the freedom of the Church. These texts needed to be cited for the sake of perspective; Leo XIII sets value on law, but he regarded its value as secondary to conditions of religious and moral health in society. Law is not the main cause of these conditions; indeed, it is effective in proportion as it is the manifestation of their existence. Whether Leo XIII was always fully faithful to this minimist concept of the value of law, especially when he touches the matter of the role of government in the religio-cultural order, is a question later to be discussed. In any event, he was not on principle a protagonist of the theory that would build society from the top down, by law. The good society will be good by reason of the creative and constructive forces of virtue active in its depths. At best, law can only protect and direct these vital forces.

What impressed his contemporaries, and dismayed some of them, was his firm theory of governmental interventionism in the socioeconomic order. The surprise and dismay were natural in the heyday of laisser-faire and of the "umpire state." What impresses us, on the contrary, in our age of totalitarianisms of the right and of the left, is the Pope's concern to set careful limits to governmental intervention. Part of this concern derived from the presence on the scene of an Enemy, European doctrinaire socialism in its various forms, verging from left to extreme left. But the main concern was to hew to the line of sound political principles. Leo XIII boldly took from the Enemy the truth that he had-the principle that government, under the conditions of modern society, must take an active role in economic life. In grasping this problem the United States, in the person of Andrew

"Allocution, Il y a deux ans (Oct. 30, 1889), Desclée, III, 283. 
Jackson, was nearly six decades ahead of Rerum novarum. Industrialism had wrought a progressive depersonalization of economic life. And the impersonality of the employer-employee relationship had in turn bred moral irresponsibility. A new "master" had appeared, the corporation. And, as the American aphorism had it, "Corporations have neither bodies to be kicked nor souls to be damned." They were seemingly immune from the restraints that conscience had imposed on the old "master," the individual, in an age when economic relationships were generally personal. The private conscience had ceased to be an effective means of social control. Therefore the only alternative to the tyranny of socialism or the anarchy of economic liberalism was the growth of the public conscience and its expression through the medium of law and governmental act-a medium whose impersonality matched the impersonality of the economic life into which it was thrust as a principle of order. On these grounds Leo XIII took his stand for interventionism. At the same time he brought the whole weight of his teaching office to bear on the more fundamental problem, the education of the public conscience. In this latter connection one rarely cited text is pertinent. It is sometimes said that Leo XIII gave too much attention to the principes, to the men who actually held the power of rule, and too little attention to the people, to the development of their capacity for self-rule. There is some ground for this charge; for it is a charge. However, the following text sets the perspectives more exactly:

It is recorded in our memory of blessed Father Francis and of his most distinguished disciples that they were men dedicated to the people and accustomed to devote their efforts with consuming diligence to the public good. Look around you now at men and at affairs. Surely you will see that it is time for you to take up again that same plan of life, and courageously imitate the example of those men of old. Certainly in this day, more than ever before, the well-being of society depends to a great extent upon the people. It is therefore the duty of both orders of clerics to know the multitude at first hand, and to come with love to its aid, teaching, admonishing, comforting; for the multitude not only bears the frequent burden of poverty and hard work but is also beset with snares and dangers. Indeed, if We ourselves have written letters to the bishops about the Masonic sect, about the conditions of the working man, about the chief duties of Christian citizens, and about kindred subjects, we have written these letters chiefly for the sake of the 
people, that they may learn from them to estimate their rights and duties, to look out for themselves, and to will that proper provision be made for their welfare. ${ }^{\text {1s }}$

There is in this text the germ of a great idea, which Leo XIII certainly glimpsed, even though he did not fully elaborate it. I mean the idea that the people are responsible for their own temporal destinies, that the well-being of society depends largely on them, that powerful dynamisms of political and social change are resident in a people which has estimated its rights and duties in a Christian sense and is determined that the popular will, formed by this estimate, should be represented when the structures of society are shaped and the direction of its movement decided upon.

At the time (1898) this idea had, of course, gone far beyond the germinal stage in the United States; behind it already lay some three centuries of growth - a growth so burgeoning as to evidence some rankness. In this sense one may perhaps feel that the Pope came rather belatedly upon the idea. In any event, within the religio-political culture of the so-called Catholic nations, in which long centuries of absolutism-royal, confessional, enlightened, Liberal-(and, one might add, equally long centuries of a "religion of the state") had left as their inheritance the Catholic masses, passive with regard to their social fate as well as indifferent to their Christian faith, the idea was hardly more than germinal.

This brief digression to Leo XIII's efforts to foster the seed of the future was made for the sake of perspective. In returning to his political concept of government, the next thing to be noted is the way he effectively dethroned the principle which he took from the Enemy on the left - the principle of interventionism-from the status it had in the Enemy's camp, the status of an absolute. Governmental intervention is not an absolute, any more than "free enterprise" (as the Enemy on the right understood the term) is an absolute. Intervention is relative to the proved social damage or danger consequent on social imbalance and disorder. At the same time, Leo XIII was not captive to the doctrinairism latent in the pseudo-axiom, "That government governs best which governs least." He actually took the ground from under the later argument, which was pitched on a sort of quantitative

11a Letter to the General of the Order of Friars Minor. 
statement of the question: Is there "too much" government? That is not the question. Rather, the question in Leo XIII's mind was: Is government promoting "too much" or "too little" the interests of a particular class or group?

Leo XIII's relativist and realist concept of the political role of government in economic and social life preserves him from the doctrinairism of both the Right and the Left. It reveals a healthy distrust of government when it begins to infringe upon the freedom of society and its natural and free associational forms. At the same time it reveals a sound respect for government when it acts within the limits of social necessities created by irresponsible uses or abuses of freedom. Moreover, even when Leo XIII urges upon government a special care of the miserum vulgus, he is not recommending a paternalistic attitude, as if government were somehow to become the Father of the Poor. On the contrary, even the special function of government with regard to the disinherited masses remains a political function. It is discharged through the political medium of law. Its proper motive is justicesocial and distributive. Its proper end is the end of justice, which is equality - not indeed the illusory "equality" of Marxist or Socialist theory, but the real equality which lies in the intentions of nature and is promoted by just laws which enforce rights and responsibilities, promote an equitable distribution of property, achieve a rightful harmony of particular social interests, and look to a just balance of that power within society which is related to property.

If one wished to sum up Leo's political concept of government in its relation to the socio-economic order, one might well use the phrase, "As much freedom as possible, as much government as necessary." (The phrase has a good American ring, whatever one's judgment may be on the manner and success with which the U.S. has applied it.) It should be noted that this political concept of government has what may be called a strongly existential flavor. The general principle upon which it is based is extremely broad - the obligations of government to the common good and to the social values which are common goods, such as justice, freedom, a due measure of equality, public prosperity and peace, etc. The applications of the principle are subject to the canons of political prudence. And the exercise of this virtue supposes a close analysis of existent social fact and of the existent state of balance 
or imbalance among social powers, as well as a reasoned judgment with regard to the probable good and evil which would result from governmental action. Speaking only per se, one cannot say very much about government in its relation to economic life; to speak with concrete meaning, one must speak in terms of contingent fact.

\section{THE PATERNAL CONCEPT}

When one turns to consider Leo XIII's concept of government in relation to the order of religion and culture, one notices certain similarities, and also an important difference. What appears in the first instance is a striking similarity - or, one would better say, an analogy. The premise of his political concept of government is the distinction between the political order as such and the socio-economic order. The latter has its own autonomy, its own inherent dynamisms, its own interior principle of vitality, as it were. If one could legitimately speak of "ideals" in the matter, the ideal would be a socio-economic order which would be entirely self-governing and free ("Without a doubt, the intervention and action of these [public] powers are not indispensably necessary...”). In other words, interventionism is not of the essence of government-supposing for the moment that one could speak meaningfully of government as having or being an "essence." Moreover, even when receding from the "ideal" (if there be such a thing) under pressure of the necessities of an existent society, the task of government remains, on principle, a political task - that of ordering what is "there." It is the task of creating by law a true order of freedom among the various self-governing functional bodies to whose immediate charge the socio-economic enterprise is committed. It may be that the existent necessities of a given society require that government should initially assist in calling into existence these functional bodies which "give form and shape to all economic life" (Pius XI). But this too is a political task, which ultimately looks to the freedom of the order of economic life. In principle, therefore, the essential function of government is not intervention, but the promotion, protection, and vindication of a truly free, self-governing, and ordered economic life.

Here the analogy appears. The basic premise of Leo XIII's theory of the relation of government to the order of religion is that this order, even more than the socio-economic order, is an order of life distinct 
from the political order. More specifically, it is clear that he assigns to government, as its essential task, that of promoting, protecting, and vindicating the freedom of that self-governing functional body to which the charge of man's religious life has been committed, namely, the Church. There is, I say, only analogy here; for the Church is not a sort of "industry council," not one of the ordines of which Pius XI speaks in Quadragesimo anno, clarifying Leo XIII. Nor can government have any function at all in calling the Church into existence; for the Church as a society is already "there," existent on a title uniquely hers. Her existence does not derive from some collective human act of free association, nor even from a tendency inherent in nature; much less from any act of political authority whereby legal status in society would accrue to her. The Church exists by divine act and will; her freedom, like her origin and finality, is of the transcendent order. The freedom of the Church is a participation in the freedom of the Incarnate Word Himself, and all her members participate in this freedom.

The phrase, "the freedom of the Church," states the dominant theme of Leo XIII's whole pontificate; it recurs dozens and dozens of times, in almost every important document. The emphasis on it has indeed a polemic import: "Let us defend the freedom of the Church with all the more constancy in proportion as embittered adversaries make every endeavor to reduce her to slavery." 12 The emphasis derives too from the pressure of the Roman Question. But this was accidental, although the accidentality was most providential. The emphasis in the first instance derives from sheer principle; Leo XIII reasserts with new clarity the central truth of tradition. (It had, one may think, become somewhat obscured during the long ages during which Hildebrand's Enemy, the Eigenkirche, had risen in a new form, the national statechurch, wherein the Church had bought legal security at the price of some greater or less diminution of her freedom - a freedom, be it noted, which belongs to her as the Church Universal, and which is invariably diminished by any "nationalization" or "legalization.")

Leo XIII asserts the freedom of the Church on two grounds. In the first instance he asserts it as a matter of divine right, inherent in the Gospel itself, part of whose message of salvation was the proclamation of the freedom of man's religious life from the control of any earthly

${ }^{12}$ Letter, Descriptio rerum (April 27, 1889), Desclée, III, 244. 
Caesar. The assertion of Christian and ecclesiastical freedom on these transcendent grounds is frequent and insistent. However, it is distinctive of Leo XIII that he made the assertion with almost equal frequency and almost comparable insistence on another ground, namely, on the ground of political principle. I am referring to his constant linking of the freedom of the Church with the common good of society. In consequence of this link, the freedom of the Church becomes a matter of political principle, a first principle of politics, binding on government, making cura libertatis Ecclesiae the essential duty of government in regard to the religious order. The texts in this sense are too numerous for quotation. They all restate in one way or another the basic enthymeme: True religion is the good (one might capitalize, The Good) of society; therefore the Church must be free to make society religious. Before giving a selection of texts, it might be parenthetically remarked that this enthymeme is part of the premise of the First Amendment to the Constitution of the United States; it imparts to "freedom of religion" in the American sense a meaning quite different from that which the phrase had in the totalitarian democracies of Continental Europe and Latin America, where it meant predominantly the freedom of society from religion, and, with consequent concreteness, governmental action against the freedom of the Church.

The major Leonine theme, that true religion is a social good of the highest order, received the first of its many orchestrations in the Encyclical, Inscrutabili (1878). The consequent theme, that therefore the Church must be free, is introduced almost simultaneously in the Letter, Solatio Nobis, to the Archbishop of Cologne in the same year: an understanding of the Church and a knowledge of history alike show that "the commonwealth most fully flourishes when the Church enjoys her full freedom of action; but as often as this freedom is hampered by bonds, power accrues to principles and ideas by which all manner of societal forms are undermined and dissolved." 13 The Encyclical, Quod apostolici muneris (1878), calls attention to the resources which the Church of Christ possesses against the threat of Socialism-resources of an efficacy "that does not reside in human law, nor in the coercive use of power, nor in the arms of soldiers." Then, in one of his customary addresses to principes, civil rulers, the Pope concludes:

${ }^{13}$ Letter, Solatio Nobis (Dec. 24, 1878), Desclee, I, 47. 
"Let them restore the Church to that condition of freedom in which she may exert her saving influence toward the good of all human society." 14 From 1878 onward to the end the theme develops. Three more specimen-quotations may be given. In the Encyclical, Quod multum (1886), to the Hungarian episcopate: "Wherefore [sc., by reason of the saving social influence of religion] those who hold civil power could do nothing wiser or more opportune than to allow religion, free and unimpeded, to have its influence on the minds of the people, summoning them by its precepts to an integrity of moral life." 15 Again the Letter, Etsi gratum (1899): "It ought to be a common desire that human society should be subject to the gentle sway of Christ, and that even the civil powers should know and reverence the royal rights which were divinely given Him over all nations; thus it would come about that the Church of Christ, which is His realm, would continually grow, and would enjoy that freedom and peace which is necessary for new and greater achievements." 16 Finally, in the Letter, Pastoralis vigilantiae (1891): "For this reason [sc., the relations between Christianity and good citizenship], the interests of the commonwealth are effectively furthered when the Church is allowed to exercise that freedom of action which she claims by right, and when in friendly fashion the way is opened for her widely to deploy her beneficent influence, and to devote to the common good all the resources with which she is endowed." 17

Perhaps these texts, from among many which might be adduced, ${ }^{18}$ will serve to indicate the stress laid by Leo XIII on what he calls "principium ex praecipuis, quod est Ecclesiae libertas."19 The point here is that stress is laid on this principle as a political principle, a principle of political order and social salvation. In virtue of this funda-

${ }^{14}$ Encyclical, Quod apostolici muneris (Dec. 28, 1878), Desclée, I, 58.

${ }^{15}$ Encyclical, Quod multum (Aug. 22, 1886), Desclée, II, 221.

${ }^{16}$ Letter, Etsi gratum (July 21, 1889), Bonne Press, VI, 76.

${ }^{17}$ Letter, Pastoralis vigilantiae (June 25, 1891), ASS, XXIV, 69.

${ }^{18}$ Cf., e.g., in a volume selected at random, Desclée, II, 122, 135, 180-81, 189, 222, 258,274 .

${ }^{10}$ Letter, Magni animi (May 3, 1892), ASS, XXIV, 653; the French version, Notre consolation, has "principe fondamentale de la liberté de l'Eglise" (ibid., p. 646). Incidentally, in this same context the familiar constellation of ideas recurs: the common goodtherefore religion in society - therefore the freedom of the Church. The Pope states as his "aim": "la religion et par la religion le salut de la société, le bonheur des peuples." 
mental principle the essential duty of government toward the order of human life which is religious consists in respect for the freedom of the Church. It should be noted that this duty is part of the general duty of government toward the common good, toward that manner of human welfare which is public and temporal in character. The religious salvation of society is not an affair of government; still less is the salvation of souls. The role of government, and its essential contribution in this field, remain on principle always political, not religious. The essential action of government, here as in the case of the socioeconomic order, is an action in favor of freedom. The essential duty of government is not directly toward religion in society, even though religion be integral to the common good. It is directly a duty to the autonomous, natively free society - in the case, the Church - to which alone the religious salvation both of individuals and of society itself has been committed. In this respect Leo XIII's theory of the relation of government to the order of religious life maintains a certain parallelism with his theory of the relation of government to the order of economic life.

This parallelism permits a conclusion. It would be in the line of his thought to say that, as the "intervention and action of the public powers are not indispensably necessary" under conditions of perfect order in economic life, so a fortiori they are not indispensably necessary in regard of religious life. Speaking per se (if any one may so speak), and in some sort of "ideal" order (if such a thing is conceivable), even that manner of governmental action which consists in a legal guarantee of the freedom of the Church is not indispensably necessary. No freedom needs legal guarantee unless it has enemies, who would damage or menace it. But in an "ideal" religio-social order, the freedom of the Church would have no enemies, just as in an "ideal" socio-economic order there would be no threats to justice or other moral values, and all the requisite "industry councils," etc., would be present, competent to govern the socio-economic order without political assistance, much less intervention. Doubly a fortiori, in an "ideal" religio-social order there would be no such thing as legal establishment of religion and coercive treatment of dissenters. In such an "ideal" order there are ex hypothesi no dissenters; and why should religion be legally established if it is already completely free and secure in its public existence? 
The principle of Leo XIII would seem by all means capable of extension: if any sort of legal armature is to be furnished to the religious order of society (whether in the form of a legal guarantee of freedom of the Church, or in the more drastic and demanding form of legal establishment), this should come about only on the title that controls all governmental action-the title of proved social necessity, created by serious social dangers or damage. But this title is discovered only on the plane of history, the plane of the non-ideal, where the freedom of the Church, like the moral value of justice, is menaced by forces which ought not to exist, because they are evil, but which do nonetheless exist, as a matter of fact.

I should perhaps confess that in saying all this I am speaking in an idiom which I find alien. However, the idiom is used; people do speak of an "ideal" order of things - an order, seemingly, in which error, dissent, injustice, etc., would have no place. So, for instance, they speak of an "ideal" state, of an "ideal" relationship between Church and state, or of an "ideal" socio-economic order. As if such "ideals" could become existent, and therefore relevant subjects of discourse. They cannot, of course, become existent. In what concerns religion, for instance, the order of existence is subject to the predestining decree of God, in consequence of which (however the matter may be explained theologically) not all men are among the elect. That is to say, the permanent, irremediable, existential, divinely willed situation of the human race is a condition of religious pluralism: "Do you think that I have come to bring peace on earth? No, believe me, I have come to bring dissension. Henceforward five in the same house will be found at variance, three against two and two against three..." (Luke 12:51-52). This text states an operative divine norm for human existence. Medieval Christendom did not escape the operation of this norm; much less did the so-called Catholic nations. The fact that these particular, relatively small territorial groups should have found some sort of substantial religious unity does not represent the operation of some singly valid norm; as if unity alone were the norm, and as if the pluralism of dissent were somehow abnormal. These small localized Christian unities were a matter of historical accident-providential, if you will, but accident nonetheless. And one does not project norms or ideals from a basis of historical accident, contingent fact. In any 
event, if one must speak of "ideals," in order perhaps to clarify principles, one would have to say that Leo XIII, when he is speaking solely in terms of an "ideal," would assign to government, as its single essential duty in regard of the religious order, a respect for the freedom of the Church. Unlike "industry councils," which "give form and shape to economic life," the Church is already "there," as the society which actually gives form and shape to religious life. All it needs, speaking per se, is freedom. Beyond this duty to the freedom of the existent Church, government has no essential duties in the area of religious life. If it has any other duties, they must be accidental, consequent upon social fact and social necessities of the historical, not theoretical, order. ${ }^{20}$ This would seem to be the conclusion which is authorized on grounds of the analogy which appears when one examines Leo XIII's concept of the relation of government to the non-political orders of society.

The question now is, what further theory of interventionism on the part of government in the order of religion and culture is to be found in the text of Leo XIII. The answer will be given under two headings: (1) his (incomplete) theory of governmental intervention in the general field of ideas, which was evolved in the course of his polemic against the "modern liberties," as these were conceived in the Continental

${ }^{20}$ Since I am here dealing with duties which fall directly on government, I leave out of consideration the duty of social worship. As the adjective implies, this duty falls directly on society, as a whole and in its various associational forms. Moreover, the duty of organizing diverse acts of public cult falls upon the Church; the res sacra which is public cult is singly in her charge. In this matter the duties of government as such are quite simple. They are discharged when governmental officials participate in the occasional acts of cult whereby society attests its acknowledgement of the divine sovereignty, its thanksgiving to God, its need of divine governance, etc. Since the government official is present in his representative capacity - as the representative of society in its highest form of association, which is political-his presence and participation take on the character of a symbol. They are symbolic of the recognition by society at large of its duty of social worship. The governmental duty with which the text deals is rather the duty of rendering service to God by rendering service to the common good of society. (This duty is continuous: "obligat semper et pro semper," in the sense that all acts of government are bound by it. In contrast, the duty of social worship is occasional; e.g., the prayers made on occasion of the opening of the legislative assembly, the proclamations made on occasion of national disasters or joys, etc.) Government renders its essential service to God-i.e., to the good which is true religion in society-by serving the freedom of the Church. This social good is procured directly by the Church, not by government: "The Church, not the state, shows the way to heavenly things," as Leo XIII puts it in Immortale Dei. 
totalitarian-democratic Kulturstaat; (2) his special theory of governmental "toleration" in the field of religion proper. The further question then will be, whether these theories are "pure" theories, or whether they are designed to cover the exigencies of a particular set of historical conditions and to confront the counter-claims of a particular Enemyand if so, to what extent. It will be suggested that these theories are importantly related to the contingent historical fact of the imperita multitudo, which figures in Libertas as the counterpart of the miserum vulgus of Rerum novarum. It will also be suggested that they repose to some extent on a concept of government as paternal, and not simply political, in character - a concept which is hypothetical and historically conditioned. 